http://dx.doi.org/10.18778/1429-3730.39.04

MirosławaWitkowska-Dąbrowska*

\title{
STAN ZRÓWNOWAŻENIA DOSTĘPU DO INFRASTRUKTURY LINIOWEJ OCHRONY ŚRODOWISKA W REGIONACH O DUŻYM UDZIALE OBSZARÓW PRAWNIE CHRONIONYCH
}

\author{
SUSTAINABLE ACCESS TO LINEAR ENVIRONMENTAL PROTECTION \\ INFRASTRUCTURE IN REGIONS WITH A HIGH PERCENTAGE \\ OF AREAS PROTECTED BY LAW
}

\begin{abstract}
Summary
the research presented in this paper covered the areas of the Warmia-Mazury voivodeship, which is characterized by a large share of legally protected areas. Based on statistics published by the GUS and data provided by GDOŚ and RDOŚ in Olsztyn, an analysis was carried out taking into account the horizontal and vertical division of rural, urban and urban-rural communities. The analysis included changes in the access to linear environmental protection infrastructure and changes in the share of legally protected areas in three types of municipalities in the years 2005-2012. The research revealed large disparities in the availability of environmental infrastructure in different types of municipalities, although these disparities slowly decreased. At the same time, rural communities with limited access to environmental infrastructure had significantly higher shares of legally protected areas than urban and urban-rural areas. However, the rate of change in the case of protected areas has been constant since 2007 .
\end{abstract}

Key words: linear infrastructure, environmental protection, nature protection, sustainable access, pace of change

JEL classification: Q01, Q58

\section{Wstęp}

Do lat 90. XX wieku Polska była jednym z najbardziej zanieczyszczonych krajów w Europie. Industrializacja i urbanizacja kraju odbywała się bez respektowania zasad ochrony środowiska i ochrony przyrody. Względy społeczne lub gospodarcze przeważały nad ekologicznymi. Znaczącym impulsem na drodze do

\footnotetext{
* Dr inż., Uniwersytet Warmińsko-Mazurski w Olsztynie, Katedra Ekonomiki Przestrzennej i Środowiskowej.
} 
równoważenia rozwoju, również w aspekcie środowiskowym okazała się wówczas bliska perspektywa przystapienia Polski do Unii Europejskiej. Przepisy Traktatu Akcesyjnego stawiały poważne zadania do wypełnienia, z generalną tezą, że po roku 2015 Rzeczpospolita Polska powinna być krajem spełniającym wszystkie standardy w ochronie środowiska, obowiązujące w Unii Europejskiej. W granicach całej Unii Europejskiej, w ciagu ostatnich 10 lat opóźnienie gospodarcze krajów wschodniego pogranicza sukcesywnie się zmniejszał. Jednocześnie pogłębiały się wewnętrzne różnice międzyregionalne występujące w granicach poszczególnych państw (Kosiedowski 2009: 64-75). Te różnice dotyczyły nie tylko regionów wytyczonych administracyjnie, ale również wynikały z podziału na tereny zurbanizowane i niezurbanizowane, czy też miasto i wieś. Znaczące zmiany na obszarach wiejskich w Polsce są wypadkową wielu procesów gospodarczych, społecznych, politycznych, czy kulturowych. Wielość oddziaływań na obszary wiejskie skutkuje znaczącymi różnicami w poziomie rozwoju na obszarach wiejskich. Wiążą się także z rolą uwarunkowań środowiskowych i coraz większymi wymaganiami środowiskowymi (Hefner 2009: 99-107). Od końca 2003 roku realizowano Krajowy Program Oczyszczania Ścieków Komunalnych, dotyczył on jednak przede wszystkim budowy oczyszczalni ścieków oraz systemów kanalizacyjnych w wyznaczonych aglomeracjach o wielkości powyżej 2000 równoważnej liczby mieszkańców. Co ważne zwłaszcza na obszarach o wyjątkowych walorach przyrodniczych w krajach członkowskich UE (Polityka ekologiczna..., 2008: 4-22).

Od momentu wstapienia Polski do Unii Europejskiej obowiązujące dotąd oraz nowe formy ochrony przyrody i nowe regulacje prawne spowodowały przyrost powierzchni obszarów prawnie chronionych. Dziesięć lat obecności Polski we Wspólnocie Europejskiej jest dobrym momentem do pierwszych ocen czy powiększanie się tych terenów idzie w parze z ochroną środowiska wynikającą z wyposażenia w infrastrukturę liniową ochrony środowiska.

Oczywistym jest fakt, że są różnice na terenach wiejskich i miejskich, pozostaje jednak pytanie jakie jest tempo zmian na tych obszarach i ewentualnie jaka jest szansa na wyrównanie rozwoju. Celem badań była identyfikacja zmian na obszarach cennych ekologicznie, w tym prawnie chronionych w zakresie dostępności do infrastruktury ochrony środowiska. Zakres czasowy dotyczył obecności Polski w Unii Europejskiej, od 2005 do 2012 roku. W takim przedziale czasowym statystyka powszechna pozwala na porównania wykorzystując podział na gminy miejskie, miejsko-wiejskie i wiejskie. Badaniami objęto obszar województwa warmińsko-mazurskiego, które charakteryzuje się dużym udziałem obszarów prawnie chronionych. Podczas badań przeprowadzono analizę poziomą i pionową uwzględniająca podział na gminy wiejskie, miejskie i miejsko-wiejskie. Dla wnikliwszego zobrazowania zjawisk dane województwa porównywano z danymi dla całego kraju. Źródła danych stanowiły dane GUS BDL oraz dane GDOŚ i RDOŚ w Olsztynie. W badaniach wykorzystano wskaźniki dotyczące udziału korzystają- 
cych infrastruktury liniowej ochrony środowiska oraz udziału obszarów prawnie chronionych. Obliczono dynamikę zmian z zastosowaniem indeksu o podstawie zmiennej. Za bazowy przyjmowano rok poprzedni. Obliczono również wskaźnik średniego tempa wzrostu (Timofiejuk 1990).

Powierzchnia województwa warmińsko-mazurskiego wynosi $24203 \mathrm{~km}^{2}$, stanowi 7,7\% terytorium Polski. Województwo warmińsko-mazurskie jest czwartym pod względem powierzchni w Polsce. Posiada urozmaiconą rzeźbę terenu i charakteryzuje się różnorodnością zasobów przyrodniczych z dużym udziałem wód powierzchniowych śródlądowych (ponad 6\% powierzchni). Lesistość wynosi około $30 \%$ i jest zbliżona do średniej w kraju. Ponad 54\% powierzchni stanowią użytki rolne. Liczba ludności województwa wynosi ponad 1,4 miliona osób. Gęstość zaludnienia jest najniższa w Polsce 59 osób na $1 \mathrm{~km}^{2}$. Województwo jest jednym z mniej zanieczyszczonych w kraju. Główne działy produkcji to: artykuły spożywcze i meble. Rozwija się turystyka z uwagi na korzystne walory oraz gospodarka rybacka (Witkowska, Bączkowski 2010). Wody powierzchniowe w województwie pokrywają ponad $6 \%$ powierzchni. Według stanu podanego w „Programie Ochrony środowiska Województwa Warmińsko-Mazurskiego na lata 2011-2014" zagrożeniem dla wód nie tylko powierzchniowych ale i podziemnych w województwie warmińsko-mazurskim są przede wszystkim odprowadzane i niewłaściwie oczyszczane ścieki komunalne i przemysłowe oraz spływy obszarowe. Ilość odprowadzanych do wód ścieków i zawarty w nich ładunek zanieczyszczeń może znacznie ograniczyć zdolność samooczyszczania wód powierzchniowych i doprowadzić do ich degradacji. Zawarty w ściekach ładunek związków biogennych (związków azotu i fosforu) zwiększa poziom eutrofizacji wód, prowadząc do tzw. wtórnego zanieczyszczenia wód. Zanieczyszczenie wód oddziałuje także na stan ekosystemów wodnych i od wody zależnych powodując zmiany struktury gatunkowej zasiedlających je organizmów, a w szczególności wymieranie niektórych z nich. Duże zagrożenie zarówno dla wód powierzchniowych, jak i podziemnych stanowi brak kanalizacji na terenach wiejskich przy szybko rozwijającym się zbiorowym zaopatrzeniu w wodę Często zbiorniki bezodpływowe (tzw. szamba) traktowane są jako odstojniki lub osadniki ścieków odprowadzanych do wód powierzchniowych lub do ziemi. Niedostosowane do oczyszczania stanowią często poważne źródło skażenia sanitarnego. Przy stosunkowo niewielkim jednostkowym zanieczyszczeniu fizykochemicznym, globalnie mają duży wpływ na wody gruntowe i małe cieki. Szczególnie duże znaczenie mają związki azotu, które w wyniku procesów biochemicznych mogą w niekorzystnych warunkach lokalnie znacznie zanieczyścić okoliczne studnie. Na obszarach atrakcyjnych ze względu na wysokie walory środowiskowe rozwijająca się turystyka i rekreacja przy jednocześnie słabo rozwiniętej gospodarce ściekowej, a w szczególności rekreacji indywidualnej w sąsiedztwie zbiorników wodnych stanowi zagrożenie. Ponadto rekreacyjnemu wykorzystywaniu jezior towarzyszy często proces niekontrolowanego zrzucania ścieków bytowych bezpośrednio do 
wód. W województwie warmińsko-mazurskim jakość powietrza zależy głównie od wielkości i rozkładu przestrzennego emisji ze źródeł stacjonarnych oraz mobilnych. Główną przyczyną powstawania zanieczyszczeń powietrza jest spalanie paliw, w tym: w procesach energetycznego spalania paliw kopalnych oraz $\mathrm{w}$ silnikach spalinowych napędzających pojazdy. Oprócz zakładów przemysłowych na znacznej części obszaru województwa lokalny poziom stężeń zanieczyszczeń powietrza jest kształtowany przez tzw. emisję niską pochodzącą z niedużych obiektów mieszkalnych i usługowych ogrzewanych indywidualnie oraz palenisk domowych. Podstawowym paliwem jest węgiel kamienny, którego spalanie skutkuje wyższymi stężeniami m.in.: pyłu, benzo(a)pirenu i dwutlenku siarki (głównie w sezonie grzewczym). Często są stosowane paliwa o wysokiej zawartości popiołu oraz współspalane odpady w nieprzystosowanych do tego paleniskach. Znaczący udział w emisji całkowitej ma sektor komunalny i mieszkaniowy (Program Ochrony..., 2011: 21-59).

\section{Udział obszarów prawnie chronionych w latach 2005-2012}

W województwie warmińsko-mazurskim blisko $47 \%$ powierzchni objęte jest prawnymi formami ochrony przyrody. Są to: rezerwaty przyrody, parki krajobrazowe, obszary chronionego krajobrazu, użytki ekologiczne, zespoły przyrodniczo-krajobrazowe, stanowiska dokumentacyjne, użytki ekologiczne (tab. 1). Ponadto od 2004 roku wprowadzono obszary Natura 2000, które w znaczącej części pokrywają się z w/w formami ochrony przyrody. W chwili obecnej, na terenie Polski, w tym także w województwie warmińsko-mazurskim, wyznaczone zostały Obszary Specjalnej Ochrony Ptaków (OSO) i Tereny o Znaczeniu dla Wspólnoty (TZW), (jako przyszłe Specjalne Obszary ochrony Siedlisk (SOO).

Tabela 1. Formy ochrony przyrody w województwie warmińsko-mazurskim (ha)

\begin{tabular}{|l|r|}
\hline Ogółem & $\mathbf{1 1 2 6 1 5 5 , 3}$ \\
\hline Rezerwaty przyrody & 31229,4 \\
\hline Parki krajobrazowe razem & 144931,4 \\
\hline Rezerwaty i pozostałe formy ochrony przyrody w parkach krajobrazowych & 5532,4 \\
\hline Obszary chronionego krajobrazu razem & 953400,7 \\
\hline Rezerwaty i pozostałe formy ochrony przyrody na obszarach chronionego krajobrazu & 24118,9 \\
\hline Użytki ekologiczne & 4855,0 \\
\hline Stanowiska dokumentacyjne & 2,0 \\
\hline Zespoły przyrodniczo-krajobrazowe & 21388,1 \\
\hline
\end{tabular}

Źródło: Program Ochrony Środowiska Województwa Warmińsko-Mazurskiego na lata 20112014 na podstawie danych: 64-74, GUS 2010. 
W tabeli 2 przedstawiono udział obszarów prawnie chronionych bez uwzględniania obszarów Natura 2000. Z danych statystycznych GUS wynika, że udział obszarów prawnie chronionych w województwie warmińsko-mazurskim był wyższy niż w Polsce w 2005 roku o 13,71 punktów procentowych i w 2012 roku o 14,26 punktów procentowych. Jednak w badanych latach udział tych obszarów w Polsce zmniejszył się o 0,08 punktu procentowego, a w województwie wzrósł o 0,47 punktu procentowego. Różnice były widoczne w różnych typach gmin. W gminach miejskich w Polsce ogółem odnotowano spadek o około 1,5 punktu procentowego w badanym okresie, w gminach wiejskich mniej, zaledwie o 0,07 punktu procentowego. W gminach miejsko-wiejskich w Polsce początkowo następował wzrost udziału obszarów prawnie chronionych a następnie niewielki spadek. W województwie warmińsko-mazurskim w badanym okresie odnotowano sukcesywny przyrost obszarów prawnie chronionych.

Tabela 2. Udzial obszarów prawnie chronionych* (\%)

\begin{tabular}{|l|r|c|c|c|c|c|c|c|}
\hline \multirow{2}{*}{\multicolumn{1}{|c|}{ Wyszczególnienie }} & \multicolumn{70}{c|}{ Lata } \\
\cline { 2 - 9 } & $\mathbf{2 0 0 5}$ & $\mathbf{2 0 0 6}$ & $\mathbf{2 0 0 7}$ & $\mathbf{2 0 0 8}$ & $\mathbf{2 0 0 9}$ & $\mathbf{2 0 1 0}$ & $\mathbf{2 0 1 1}$ & $\mathbf{2 0 1 2}$ \\
\hline Polska & 32,54 & 32,12 & 32,31 & 32,31 & 32,31 & 32,44 & 32,46 & 32,46 \\
\hline Gminy miejskie & 17,17 & 15,90 & 15,96 & 15,49 & 15,65 & 16,31 & 16,40 & 15,70 \\
\hline Gminy miejsko-wiejskie & 32,67 & 32,68 & 32,90 & 32,89 & 32,89 & 32,80 & 32,77 & 32,77 \\
\hline Gminy wiejskie & 33,56 & 32,98 & 33,16 & 33,20 & 33,20 & 33,40 & 33,44 & 33,49 \\
\hline $\begin{array}{l}\text { Województwo warmińsko- } \\
\text {-mazurskie }\end{array}$ & 46,25 & 46,27 & 46,29 & 46,31 & 46,47 & 46,59 & 46,72 & 46,72 \\
\hline Gminy miejskie & 8,19 & 11,90 & 12,31 & 12,31 & 12,31 & 12,31 & 12,31 & 12,31 \\
\hline Gminy miejsko-wiejskie & 50,30 & 50,33 & 50,33 & 50,39 & 50,65 & 50,79 & 51,15 & 51,15 \\
\hline Gminy wiejskie & 44,73 & 44,68 & 44,70 & 44,69 & 44,80 & 44,91 & 44,91 & 44,91 \\
\hline
\end{tabular}

*bez Natura 2000.

Źródto: BDL, GUS 2005-2012.

Dynamika zmian wykazała wahania w kolejnych latach (rys. 1). Największa zmiana dotyczyła gmin miejskich w województwie warmińsko-mazurskim w 2006 roku.

Nastąił tam wzrost udziału obszarów prawnie chronionych o ponad 45 punktów procentowych. W kolejnym roku tempo dynamiki wzrosło jeszcze o 3,4 punkty procentowe, po czym osiagnęło stałą wielkość.

Dla obszarów Natura 2000 instytucje i organy gromadzące dane statystyczne: GUS, GDOŚ, RDOŚ nie podają powierzchni obszarów w poszczególnych gminach lub przynajmniej typach gmin albo obszarów. Scharakteryzowano, więc jedynie udział obszarów Natura 2000 w Polsce i województwie z podziałem na OSO) i TZW (tab. 3). 


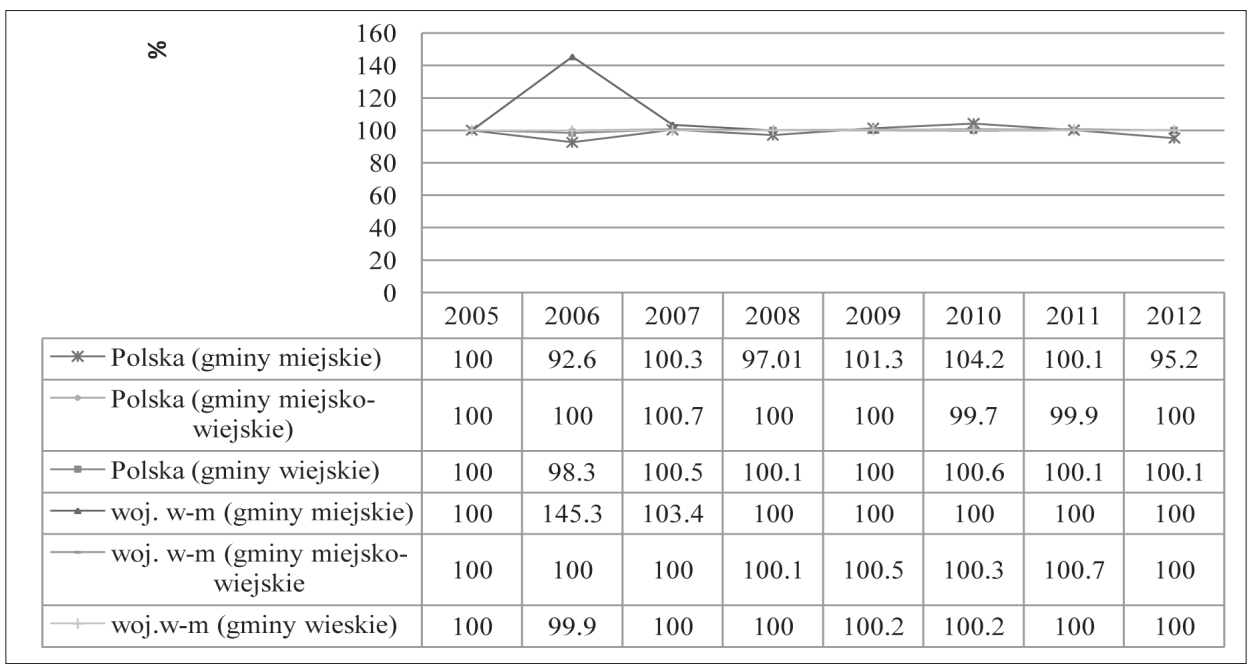

Rysunek 1. Dynamika zmian udziału obszarów prawnie chronionych wg gmin (\%) Źródto: opracowanie na podstawie: BDL, GUS 2005-2012

Tabela 3. Udział obszarów Natura 2000 w Polsce i w województwie warmińsko-mazurskim (\%)

\begin{tabular}{|l|c|c|c|c|c|c|c|c|c|}
\hline \multirow{2}{*}{ Wyszczególnienie } & \multicolumn{7}{c|}{ Lata } \\
\cline { 2 - 9 } & $\mathbf{2 0 0 5}$ & $\mathbf{2 0 0 6}$ & $\mathbf{2 0 0 7}$ & $\mathbf{2 0 0 8}$ & $\mathbf{2 0 0 9}$ & $\mathbf{2 0 1 0}$ & $\mathbf{2 0 1 1}$ & $\mathbf{2 0 1 2}$ \\
\hline \multicolumn{8}{|c|}{ OSO } \\
\hline Polska & 7,8 & 7,8 & 13,9 & 15,8 & 15,6 & 15,7 & 15,7 & 15,8 \\
\hline $\begin{array}{l}\text { Województwo warmińsko- } \\
\text {-mazurskie }\end{array}$ & 20,9 & 20,9 & 22,9 & 23,8 & 23,8 & 23,9 & 23,8 & 23,8 \\
\hline \multicolumn{8}{|c|}{ TZW } \\
\hline Polska & 3,8 & 4,5 & 8,0 & 8,2 & 11,0 & 11,0 & 11,0 & 11,0 \\
\hline $\begin{array}{l}\text { Województwo warmińsko- } \\
\text {-mazurskie }\end{array}$ & 2,8 & 4,1 & 3,6 & 3,6 & 10,7 & 10,7 & 10,6 & 10,6 \\
\hline
\end{tabular}

Źródto: opracowanie na podstawie danych GDOŚ.

Od wstapienia Polski do Unii Europejskiej stopniowo wzrastał udział terenów objętych OSO oraz TZW. W 2012 roku obszar Polski był w prawie 16\% objęty Naturą 2000 w zakresie Obszarów Specjalnej Ochrony Ptaków i 11\% przyszłych Specjalnych Obszarów Ochrony Siedlisk. W województwie warmińsko-mazurskim udziały również wzrastały stopniowo ale proporcje były odmienne. W 2012 roku OSO zajmowały aż 23,8\% powierzchni województwa, a TZW 10,6\%. Obszary Specjalnej Ochrony Ptaków w województwie warmińsko-mazurskim powołano głownie dla ochrony ptactwa wodno-błotnego. Ze względu na liczne zbiorniki wodne występują duże potrzeby w tym zakresie. W badanych latach dynamika zamian wykazała, że najintensywniej obszarów Natura 2000 przybywało do 2009 roku. W latach 2010-2012 dynamika wahała się i w przypadku TZW stwierdzono 
niewielki spadek w województwie i w Polsce. Te obszary właśnie do 2009 roku charakteryzowały się szczególnie dużą dynamiką zmian (rys. 2).

Rysunek 2. Dynamika zmian udziału obszarów Natura (\%)

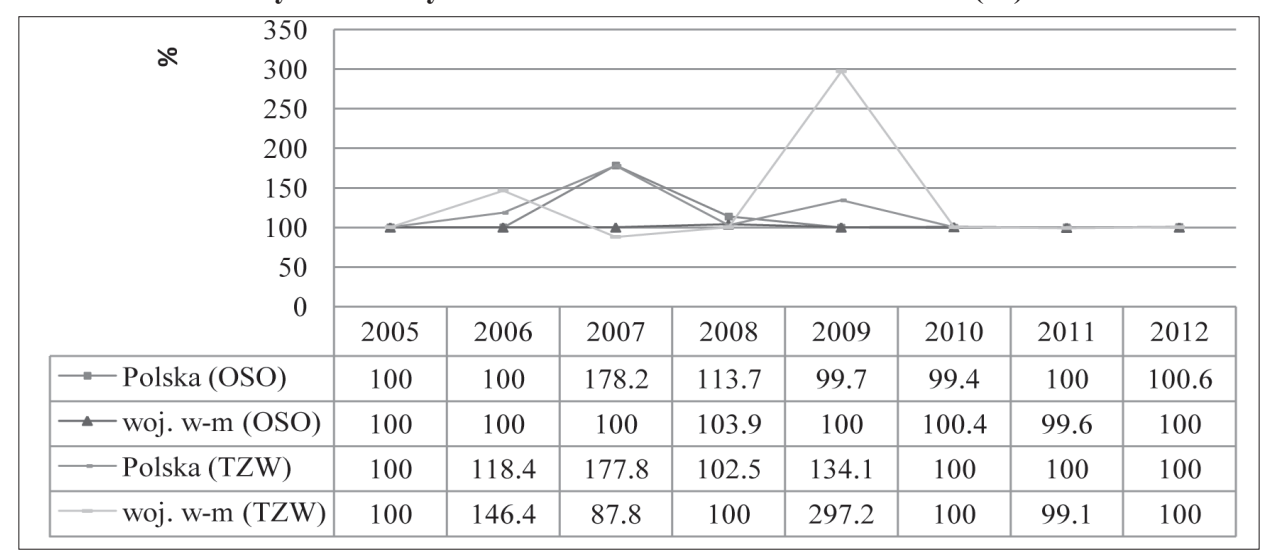

Źródło: opracowanie na podstawie: BDL, GUS 2005-2012.

W 2007 roku w Polsce Udział OSO wzrósł o 77,8\% w stosunku do poprzedniego, a w województwie zmalał o 12,2\%. Tempo zmian w następnym roku w Polsce zmalało aż o 75,3\%. W województwie największą zmianę odnotowano w 2009 roku. Udział obszarów wzrósł o 197,2\%, w Polsce w tym czasie o 34,1\%. W latach 2005-2012 odnotowano spadek udziału obszarów prawnie chronionych w gminach miejskich w Polsce o prawie 2 punkty procentowe i jednocześnie w gminach miejskich województwa największy przyrost o ponad 3 punkty procentowe (rys. 3).

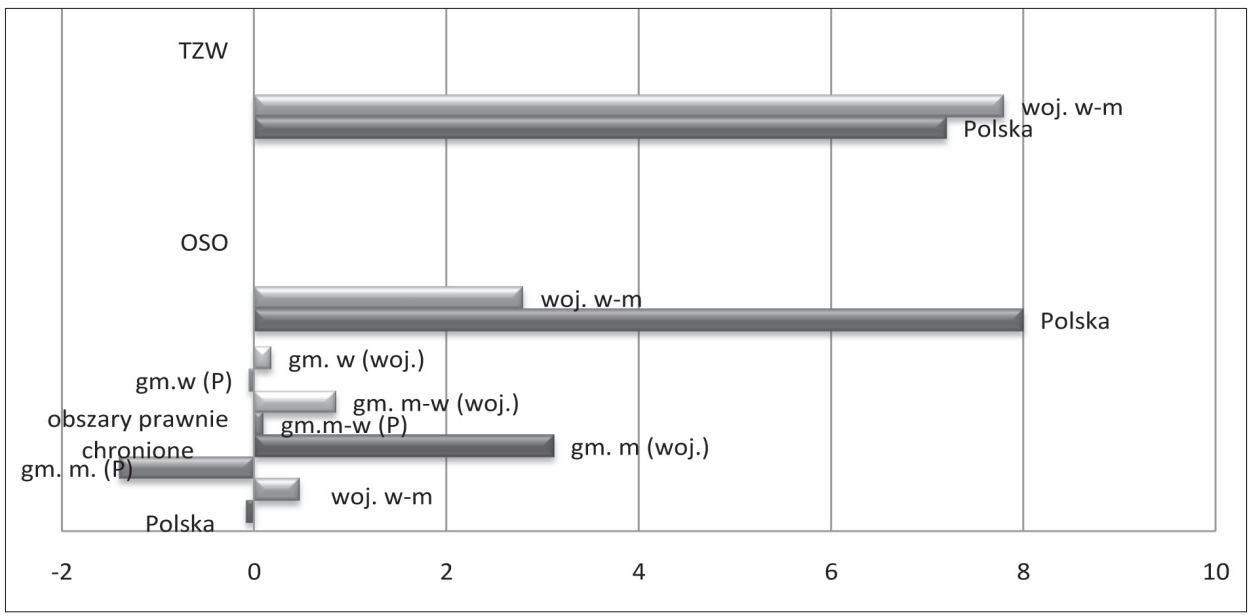

Rysunek 3. Przyrost udziału obszarów prawnie chronionych w latach 2005-2012 (punkty procentowe)

Źródło: opracowanie na podstawie: BDL, GUS 2005-2012 
W województwie warmińsko-mazurskim jest 16 OSO o łącznej powierzchni 575809 ha oraz 43 obszary TZW o powierzchni 258190 ha. Łącznie obszary Natura 2000, uwzględniając ich części wspólne, zajmują 664990 ha, czyli 27,6\% powierzchni województwa.

\section{Dostępność infrastruktury liniowej ochrony środowiska w latach 2005-2012, w trzech typach gmin na obszarze Polski i województwa warmińsko-mazurskiego}

Do zobrazowania dostępności do infrastruktury ochrony środowiska wykorzystano wskaźniki udziału korzystających z sieci wodociągowej, kanalizacyjnej, gazowej. Z badań wynika, że dysproporcje w zakresie udziału ludności korzystającej z urządzeń sieciowych w gminach wiejskich, miejsko-wiejskich i miejskich były duże zarówno w województwie warmińsko-mazurskim, jak i w całym kraju (tab.4). Szczególnie dotyczyło to sieci gazowej oraz kanalizacyjnej.

Tabela 4. Udział ludności korzystającej z infrastruktury liniowej (\%)

\begin{tabular}{|c|c|c|c|c|c|c|c|c|}
\hline \multirow{2}{*}{ Wyszczególnienie } & \multicolumn{8}{|c|}{ Lata } \\
\hline & 2005 & 2006 & 2007 & 2008 & 2009 & 2010 & 2011 & 2012 \\
\hline \multicolumn{9}{|c|}{ Udział ludności korzystającej z sieci wodociagowej (\%) } \\
\hline Polska & 86,1 & 86,4 & 86,7 & 87,0 & 87,3 & 87,4 & 87,6 & 87,9 \\
\hline Gminy miejskie & 95,3 & 95,4 & 95,4 & 95,6 & 95,7 & 95,7 & 95,8 & 95,8 \\
\hline Gminy miejsko-wiejskie & 83,4 & 83,6 & 83,9 & 84,3 & 84,4 & 84,7 & 84,9 & 85,2 \\
\hline Gminy wiejskie & 72,0 & 72,7 & 73,5 & 74,2 & 74,9 & 75,4 & 75,9 & 76,3 \\
\hline $\begin{array}{l}\text { Województwo warmińsko- } \\
\text {-mazurskie }\end{array}$ & 87,9 & 88,0 & 88,3 & 88,5 & 88,7 & 88,9 & 89,1 & 89,3 \\
\hline Gminy miejskie & 97,2 & 97,2 & 97,2 & 97,3 & 97,3 & 97,4 & 97,4 & 97,4 \\
\hline Gminy miejsko-wiejskie & 83,8 & 83,9 & 84,3 & 84,6 & 85,0 & 85,4 & 85,8 & 86,2 \\
\hline Gminy wiejskie & 77,1 & 77,5 & 78,0 & 78,5 & 78,9 & 79,2 & 79,7 & 80,0 \\
\hline \multicolumn{9}{|c|}{ Udział ludności korzystającej z sieci kanalizacyjnej (\%) } \\
\hline Polska & 59,2 & 59,8 & 60,3 & 61,0 & 61,5 & 62,0 & 63,5 & 64,3 \\
\hline Gminy miejskie & 86,1 & 86,3 & 86,5 & 86,9 & 87,2 & 87,5 & 88,1 & 88,4 \\
\hline Gminy miejsko-wiejskie & 47,9 & 48,8 & 49,3 & 50,0 & 50,5 & 51,2 & 52,9 & 54,0 \\
\hline Gminy wiejskie & 20,7 & 21,8 & 23,1 & 24,4 & 25,5 & 26,9 & 29,9 & 31,5 \\
\hline $\begin{array}{l}\text { Województwo warmińsko- } \\
\text {-mazurskie }\end{array}$ & 64,4 & 64,6 & 65,0 & 65,4 & 65,7 & 65,8 & 66,8 & 67,7 \\
\hline Gminy miejskie & 92,8 & 92,9 & 93,0 & 93,1 & 93,2 & 93,3 & 93,6 & 93,7 \\
\hline Gminy miejsko-wiejskie & 57,9 & 58,3 & 58,8 & 59,3 & 59,4 & 59,9 & 61,4 & 62,6 \\
\hline Gminy wiejskie & 25,6 & 26,1 & 26,8 & 27,7 & 28,4 & 29,1 & 30,8 & 32,9 \\
\hline
\end{tabular}




\begin{tabular}{|l|l|l|l|l|l|l|l|l|l|}
\hline \multirow{2}{*}{ Wyszczególnienie } & \multicolumn{7}{c|}{ Lata } \\
\cline { 2 - 10 } & $\mathbf{2 0 0 5}$ & $\mathbf{2 0 0 6}$ & $\mathbf{2 0 0 7}$ & $\mathbf{2 0 0 8}$ & $\mathbf{2 0 0 9}$ & $\mathbf{2 0 1 0}$ & $\mathbf{2 0 1 1}$ & $\mathbf{2 0 1 2}$ \\
\hline \multicolumn{7}{|c|}{ Udział ludności korzystającej z sieci gazowej } \\
\hline Polska & 51,7 & 51,8 & 51,7 & 51,7 & 52,6 & 52,5 & 52,5 & 52,4 \\
\hline Gminy miejskie & 77,3 & 77,3 & 77,1 & 76,8 & 76,9 & 76,7 & 76,4 & 75,8 \\
\hline Gminy miejsko-wiejskie & 37,0 & 37,2 & 37,4 & 37,7 & 39,8 & 40,1 & 40,3 & 40,9 \\
\hline Gminy wiejskie & 18,1 & 18,4 & 18,6 & 18,8 & 20,5 & 20,7 & 21,0 & 21,6 \\
\hline $\begin{array}{l}\text { Województwo warmińsko- } \\
\text {-mazurskie }\end{array}$ & 44,8 & 44,5 & 44,2 & 43,9 & 44,0 & 43,5 & 43,3 & 43,1 \\
\hline Gminy miejskie & 83,3 & 82,8 & 82,1 & 81,3 & 81,0 & 80,5 & 80,1 & 79,4 \\
\hline Gminy miejsko-wiejskie & 24,6 & 24,5 & 24,4 & 24,5 & 24,7 & 24,7 & 24,6 & 24,9 \\
\hline Gminy wiejskie & 3,4 & 3,4 & 3,6 & 3,8 & 4,4 & 4,5 & 4,7 & 4,8 \\
\hline
\end{tabular}

Źródto: BDL, GUS 2005-2012.

W 2005 roku ludność w gminach miejskich w województwie warmińsko-mazurskim korzystała z sieci wodociagowej w ponad 95\%, a wiejskich w ponad $72 \%$. W przypadku sieci wodociagowej województwo warmińsko-mazurskie nie odbiegało od stanu w Polsce, a nawet udział ludności korzystającej z wodociagów był wyższy we wszystkich badanych latach od udziału ogółem w Polsce o około 2 punkty procentowe. Podobna różnica występowała w gminach miejskich i miejsko-wiejskich. Większe różnice w udziale ludności korzystającej z sieci wodociągowej dotyczyły gmin wiejskich. W gminach wiejskich województwa udział ten był większy początkowo (2005 rok) o 5 punktów procentowych, niż w gminach wiejskich w kraju. Różnica zmniejszyła się do 4 punktów procentowych i od roku 2009 utrzymywała się na stałym poziomie. W 2012 roku w Polsce z wodociagów korzystało prawie $88 \%$ populacji, w województwie ponad $89 \%$. W gminach wiejskich odpowiednio: 76,3\% i 80,0\%. Różnice pomiędzy typami gmin zmniejszały się sukcesywnie.

W wodociągi wyposażone są wszystkie miasta i gminy województwa. Wysokie wskaźniki gęstości sieci wodociagowej rozdzielczej (średnio $351,1 \mathrm{~km} / 100 \mathrm{~km}^{2}$ ) występują w miastach. Na obszarach wiejskich wskaźnik jest niski i wyniósł 48,3 km/100 km² przy średniej dla województwa $55,9 \mathrm{~km} / 100 \mathrm{~km}{ }^{2}$ $\left(85,5 \mathrm{~km} / 100 \mathrm{~km}^{2}\right.$ - średnia krajowa). Liczba gospodarstw domowych korzystających ze zbiorowego zaopatrzenia w wodę i długość sieci wodociagowej rozdzielczej systematycznie rośnie, w szczególności na terenach wiejskich. Jednocześnie sa prowadzone prace mające na celu zmniejszenie strat $\mathrm{w}$ trakcie poboru wody i jej przesyłania, poprawienia jakości wody i obniżenia kosztów eksploatacji (Program Ochrony..., 2011).

W całym badanym okresie 2005-2012 udział ludności w Polsce korzystającej z dostępu do sieci kanalizacyjnej wzrósł o prawie 10 punktów procentowych. W 2012 roku w gminach miejskich w Polsce korzystało z niej ponad 64\% ludności, w województwie ponad $67 \%$. Podobnie, jak w przypadku wodociagów, tak i w przypadku 
udziału korzystających z sieci kanalizacyjnej województwo warmińsko-mazurskie legitymowało się wyższym udziałem o około 5 punktów procentowych, a od 2008 roku o około 4 punktów procentowych niż w Polsce ogółem. Jednak udział ludności korzystającej z kanalizacji w badanym okresie w gminach wiejskich był znacząco niższy niż w miejsko-wiejskich (prawie dwukrotnie) i miejskich (prawie czterokrotnie), zarówno w Polsce jak i województwie warmińsko-mazurskim.

Sieć kanalizacyjna województwa jest rozmieszczona nierównomiernie. Wszystkie miasta są skanalizowane i tam są wysokie wskaźniki gęstości sieci kanalizacyjnej (śr. 339,3 km/100 km²). Na obszarach wiejskich wskaźnik ten jest niski i wynosił $10,7 \mathrm{~km} / 100 \mathrm{~km}^{2}$ przy średniej dla województwa równej $18,8 \mathrm{~km} / 100 \mathrm{~km}^{2}\left(32,0 \mathrm{~km} / 100 \mathrm{~km}^{2}\right.$ - średnia krajowa). Długość sieci kanalizacyjnej i liczba gospodarstw domowych korzystających z kanalizacji sanitarnej systematycznie rośnie. W gminach o mniejszej dostępności do sieci kanalizacyjnej ludność w większym stopniu korzysta z przydomowych oczyszczalni ścieków oraz szamb i taboru asenizacyjnego (Program Ochrony Środowiska Województwa Warmińsko-Mazurskiego na lata 2011-2014).

Największe dysproporcje dotyczyły udziału korzystających z sieci gazowej. Udział ludności ogółem Polsce korzystającej z sieci gazowej, to niewiele ponad $50 \%$. W województwie o 9 punktów procentowych mniej, na dodatek mniej niż w pierwszym badanym roku o prawie 2 punkty procentowe. Udział ludności korzystającej z sieci gazowej przyjmował nieznaczne wahania. W konsekwencji spadek udziału korzystających z sieci gazowej dotyczył gmin miejskich w Polsce oraz województwie (rys. 4).

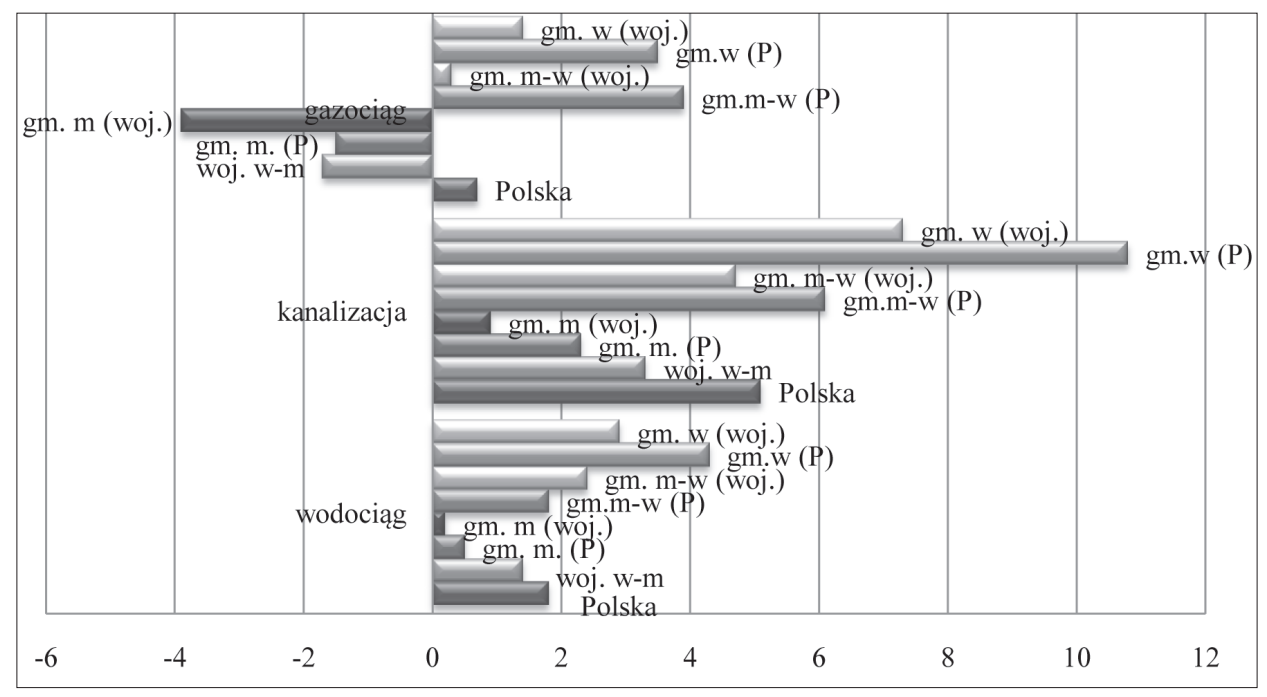

Rysunek 4. Przyrost udziału ludności korzystającej z infrastruktury liniowej między w latach 2005-2012 (punkty procentowe)

Źródto: opracowanie na podstawie: BDL, GUS 2005-2012 
sieci gazowej w gminach miejskich, miejsko-wiejskich i wiejskich. W gminach wiejskich w Polsce w 2012 roku udział korzystających osiągnął 21,6\%, ale w gminach wiejskich województwa zaledwie $4,8 \%$.

Dla bardziej szczegółowego zobrazowania problemu obliczono dynamikę zmian w udziale ludności korzystającej z infrastruktury liniowej ochrony środowiska (rys. 5). Za bazowy przyjęto rok poprzedni (indeks o podstawie zmiennej).

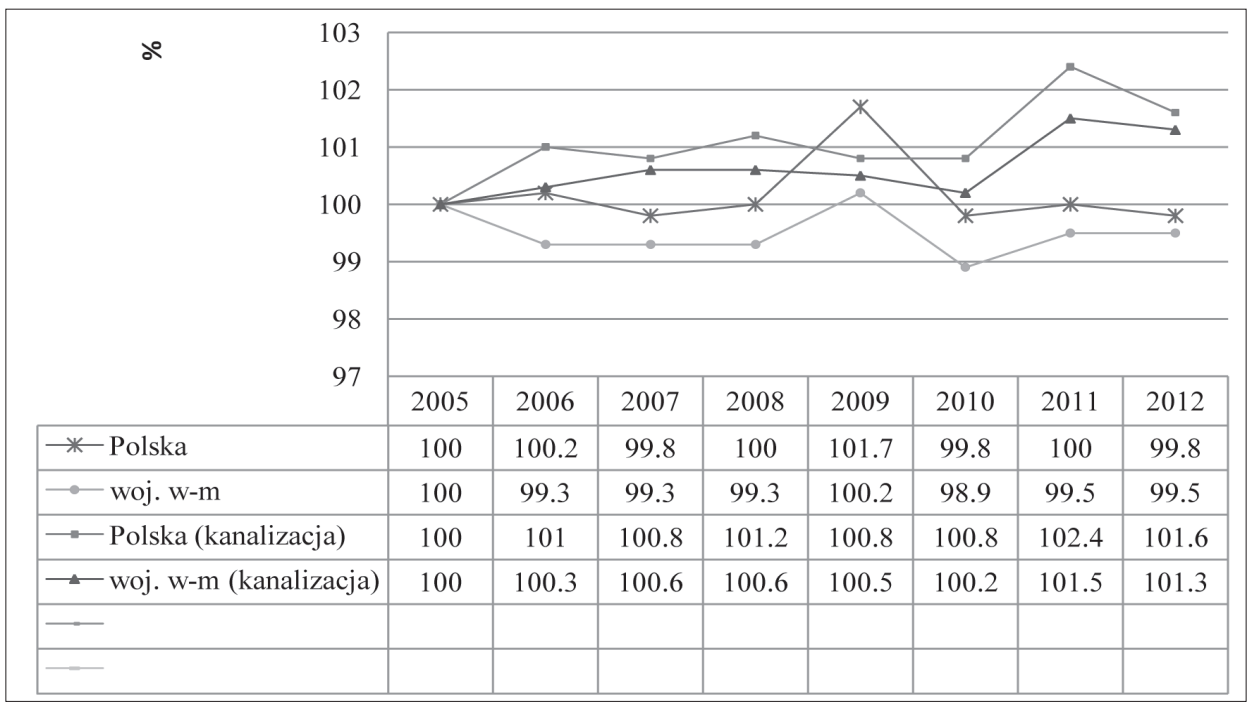

Rysunek 5. Dynamika zmian udziału ludności korzystającej z infrastruktury liniowej (\%)

Źródto: opracowanie na podstawie: BDL, GUS 2005-2012.

W badanym okresie stwierdzono sukcesywny wzrost udziału korzystających z sieci kanalizacyjnej i wodociagowej. Dynamika zmian z indeksem o podstawie zmiennej wskazuje dość stały poziom wzrostu, z niewielką przewagą w przypadku sieci kanalizacyjnej. Są to jednak zmiany sięgające w najlepszym przypadku niewiele ponad 2 punktów procentowych. Najczęściej $0,2-0,3 \%$. W przypadku udziału korzystających z sieci gazowej odnotowano w większości badanych lat spadek w stosunku do poprzedniego roku, zwłaszcza w województwie warmińsko-mazurskim.

Biorąc pod uwagę typ gmin (rys. 6) stwierdzono, że w gminach miejskich dynamika udziału korzystających z wodociagów w badanych latach była najmniej zmienna i oscylowała wokół $100 \%$. Największą dynamikę stwierdzono w gminach wiejskich: w Polsce w latach 2005-2010, a w województwie od 2009 roku.

W przypadku dynamiki zmian korzystających z kanalizacji (rys. 7), podobnie jak w sieci wodociagowej w gminach miejskich dynamika była stała, około $100 \%$. W gminach wiejskich dynamika zmian była największa. Zarówno gminach wiejskich w Polsce (11\%), jak i województwie (5\%) największą wielkość stwierdzono w 2011 roku. 


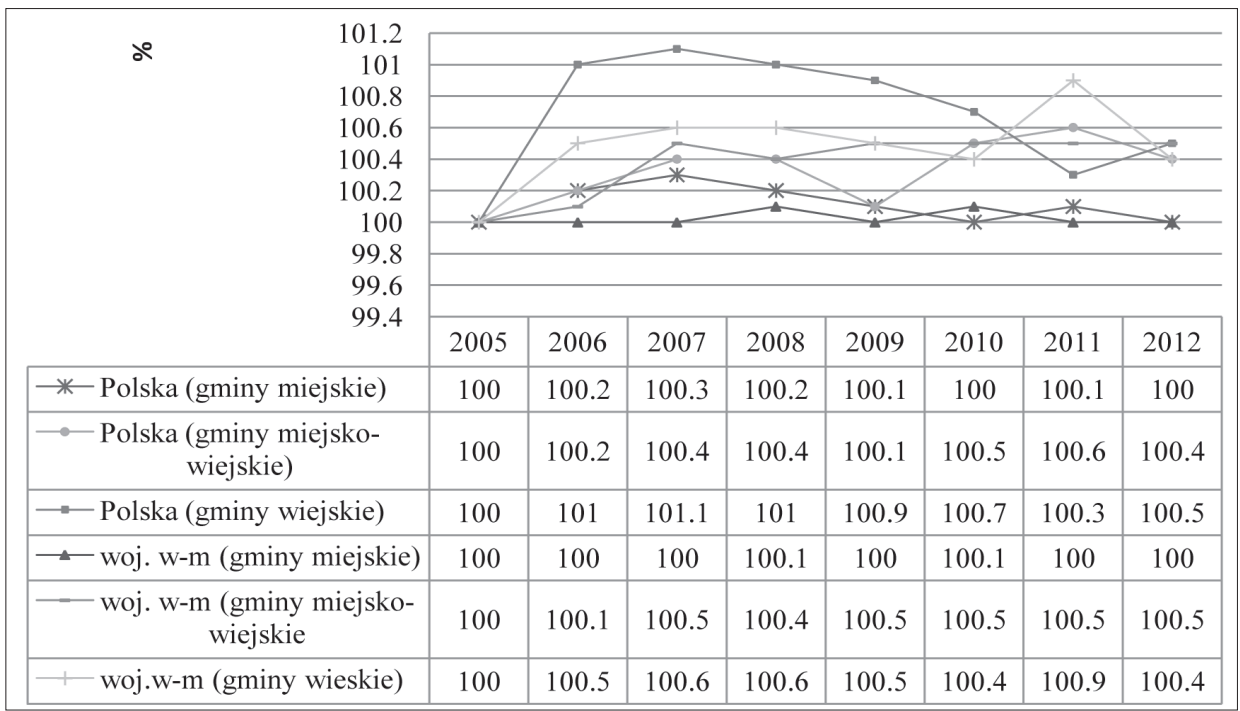

Rysunek 6. Dynamika zmian udziału ludności korzystającej z sieci wodociągowej wg gmin (\%) Źródło: opracowanie na podstawie: BDL, GUS 2005-2012.

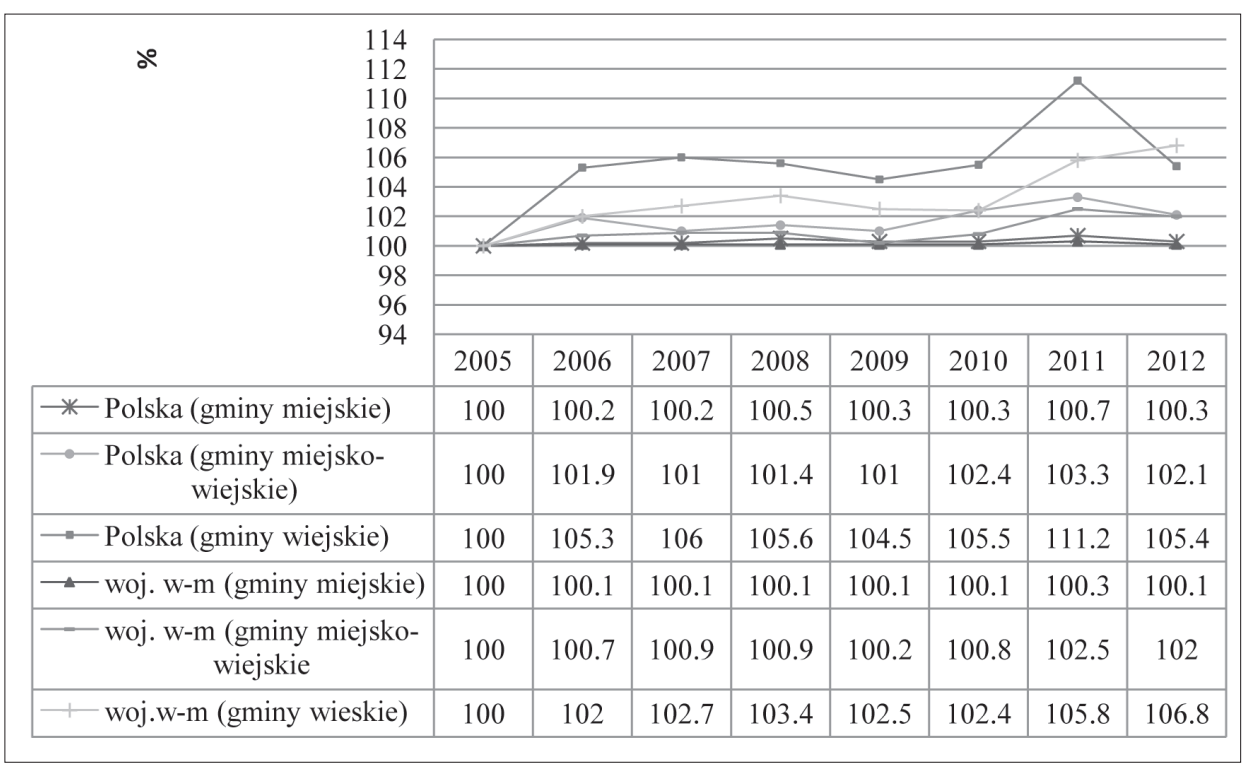

Rysunek 7. Dynamika zmian udziału ludności korzystającej z sieci kanalizacyjnej wg gmin (\%)

Źródło: opracowanie na podstawie: BDL, GUS 2005-2012.

W przypadku sieci gazowej (rys. 8) największą dynamikę zmian odnotowano również w gminach wiejskich, jednak różnice były znacząco wyższe w województwie warmińsko-mazurskim (w 2011 roku aż 15,8\%) niż w Polsce (w 2011 roku 9\%). 


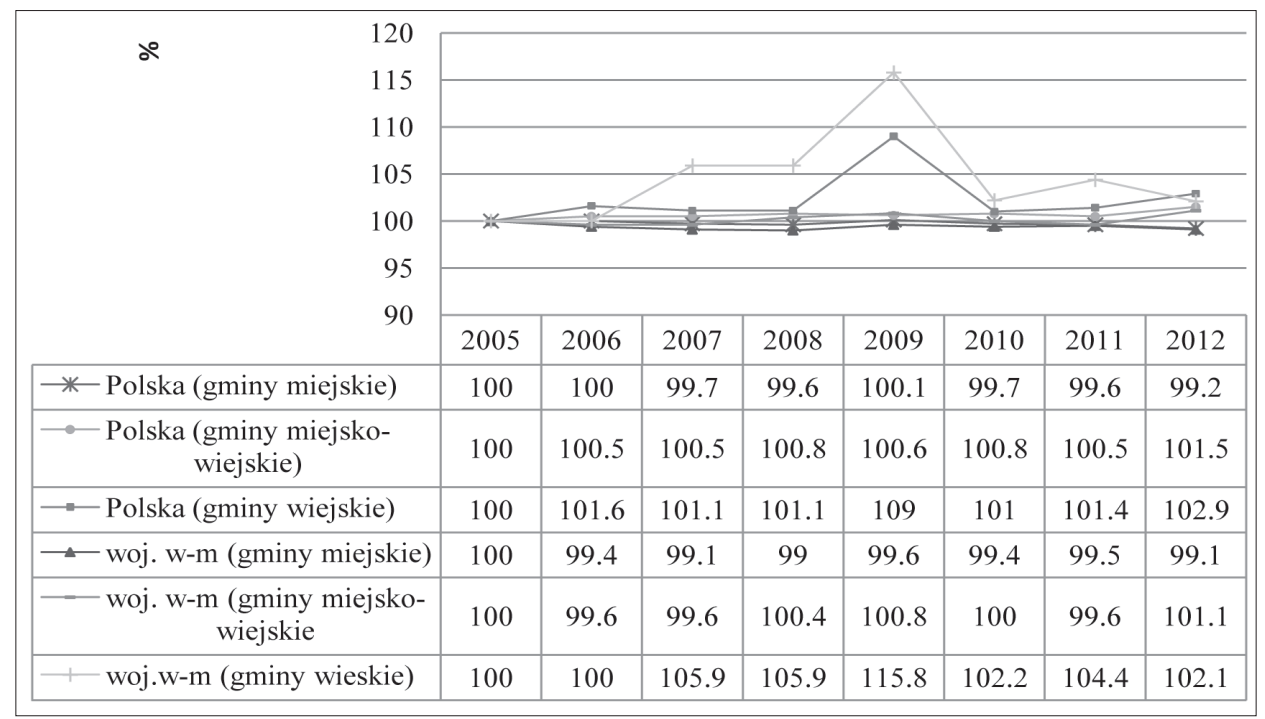

Rysunek 8. Dynamika zmian udziału ludności korzystającej z sieci gazowej wg gmin (\%)

Źródto: opracowanie na podstawie: BDL, GUS 2005-2012.

W gminach miejskich w Polsce oraz województwie w gminach wiejskich i miejsko-wiejskich w badanych latach stwierdzono wahania i spadek udziału korzystających z sieci gazowej.

Dla zobrazowania tempa zmian zarówno w powierzchni obszarów prawnie chronionych jak i infrastruktury ochrony środowiska obliczono średnie tempo wzrostu (tab. 5).

Tabela 5. Średnie tempo wzrostu (\%)

\begin{tabular}{|l|c|c|c|c|}
\hline \multirow{2}{*}{ Wyszczególnienie } & \multirow{2}{*}{$\begin{array}{c}\text { Obszary prawnie } \\
\text { chronione }\end{array}$} & \multicolumn{3}{|c|}{ Ludność korzystająca } \\
\cline { 3 - 5 } & 3,2 & wodociag & kanalizacja & gazociag \\
\hline Polska & 3,0 & 3,6 & 4,3 & 3,5 \\
\hline Gminy miejskie & 3,4 & 3,6 & 3,6 & 3,2 \\
\hline Gminy miejsko-wiejskie & 3,1 & 4,1 & 4,7 & 4,5 \\
\hline Gminy wiejskie & 3,4 & 3,5 & 3,8 & 5,5 \\
\hline $\begin{array}{l}\text { Województwo warmiń- } \\
\text { sko-mazurskie }\end{array}$ & 12,4 & 0,0 & 3,4 & 5,8 \\
\hline Gminy miejskie & 3,5 & 3,7 & 4,1 & 2,7 \\
\hline Gminy miejsko-wiejskie & 3,6 & 3,8 & 6,0 & 3,4 \\
\hline Gminy wiejskie & & & & 7,9 \\
\hline
\end{tabular}

Źródto: opracowanie na podstawie: BDL, GUS 2005-2012. 
$\mathrm{Z}$ danych wynika, że średnie tempo wzrostu w przypadku infrastruktury było największe dla korzystających $\mathrm{z}$ sieci kanalizacyjnej w gminach wiejskich, w Polsce $-8,5 \%$, w województwie dla sieci gazowej-7,9\%. W przypadku udziału obszarów prawnie chronionych najwyższe średnie tempo wzrostu odnotowano w gminach miejskich województwa $12,4 \% \mathrm{~W}$ pozostałych przypadkach zarówno rozwoju infrastruktury i obszarów prawnie chronionych tempo zmian było podobne $3-5 \%$ rocznie.

\section{Podsumowanie}

W Krajowej Strategii Ochrony i Umiarkowanego Użytkowania Różnorodności Biologicznej z 2003 roku podjęto, że całokształt działań podejmowanych we wszystkich sferach działalności człowieka powinien służyć osiagnięciu celu nadrzędnego, jakim jest: „Zachowanie bogactwa różnorodności biologicznej w skali lokalnej, krajowej i globalnej oraz zapewnienie trwałości i możliwości rozwoju wszystkich poziomów jej organizacji (wewnątrzgatunkowego, międzygatunkowego i ponadgatunkowego), z uwzględnieniem potrzeb rozwoju społeczno-gospodarczego Polski oraz konieczności zapewnienia odpowiednich warunków życia i rozwoju społeczeństwa". Ma to szczególny wydźwięk na obszarach cennych przyrodniczo, gdzie obszary obejmowane prawnymi formami ochrony rozszerzają się, a jednocześnie należałoby zadbać o utrzymanie bardzo dobrego stanu środowiska. Rozwój infrastruktury ochrony środowiska nie tylko sprzyja temu, ale wpływa na poprawę życia mieszkańców. Należy przy tym pamiętać o racjonalnym rozwoju urbanizacji z uwzględnieniem lokalnych warunków ochrony środowiska. Województwo warmińsko-mazurskie charakteryzuje się znaczącym udziałem obszarów prawnie chronionych, ale stan ten od kilku lat kształtuje się na stałym poziomie. Zmiany jakie wystapiły po akcesji Polski do unii Europejskiej w wynikały głównie z nowych możliwości wprowadzenia form ochrony przyrody. Udział obszarów prawnie chronionych w województwie warmińsko-mazurskim w latach 2005-2012 nieznacznie wzrósł, zwłaszcza w gminach miejskich i osiagnął poziom prawie $47 \%$ powierzchni, w Polsce zmalał, zwłaszcza w gminach miejskich i miejsko-wiejskich przyjmując wielkość 32\%.Udział obszarów Natura 2000 wzrósł w województwie i w Polsce, najwyższy ponad 20\% udział odnotowano w zakresie OSO w województwie. Od 2010 udział obszarów Natura 2000 ustabilizował się.

Jednocześnie też jest to obszar o wyższym poziomie dostępności do sieci infrastruktury ochrony środowiska niż średnio w Polsce z wyjątkiem sieci gazowej. Najwyższą dynamiką zmian w stosunku do roku 2005 charakteryzował się udział korzystających z kanalizacji. Udział ludności korzystającej z sieci wodociagowej oraz kanalizacyjnej wzrastał we wszystkich badanych latach w województwie warmińsko-mazurskim, jak i w Polsce, jednak był wyższy w województwie 
we wszystkich typach gmin niż w Polsce. Udział ludności korzystającej z sieci gazowej wahał się w badanych latach. W gminach miejskich w województwie, jak i w Polsce odnotowano spadek udziału korzystających z gazociagu w 3 ostatnich badanych latach. Gminy wiejskie w województwie warmińsko-mazurskim charakteryzowały się wyraźnie niższym udziałem korzystających z sieci gazowej zaledwie 5\% (w Polsce gm. 20\%). W świetle obecnych trendów wynikających ze zobowiązań Polski w zakresie energii odnawialnej należałoby raczej zbadać w przyszłości rozwój OZE na obszarze województwa. Jednak źródła energii odnawialnej nie są bezinwazyjne dla cennych przyrodniczo obszarów, wpływając chociażby na krajobraz.

\section{Bibliografia}

Hefner K. (2009), Ewolucja zróżnicowania rozwoju społeczno-gospodarczego, [w:] red. Michałowski K., Wpływ idei zrównoważonego rozwoju na politykę państwa i regionów, tom 2. Problemy regionalne i lokalne. Białystok.

Kosiedowski W. (2009), Dysproporcje rozwojowe na wschodnim pograniczu Unii Europejskiej, [w:] red. Poskrobko B., Wpływ idei zrównoważonego rozwoju na politykę państwa i regionów, tom 1. Problemy ogólnopaństwowe i sektorowe. WSE Białystok.

Polityka ekologiczna państwa w latach 2009-2012 z perspektywą do roku 2016. Ministerstwo Środowiska. Warszawa 2008.

Program Ochrony Środowiska Województwa Warmińsko-Mazurskiego na lata 2011-2014, Olsztyn 2011.

Timofiejuk I. (1990), Tablice średniego tempa wzrostu wedtug metody, Warszawa.

Witkowska M., Bączkowski T. (2010), Indicators of warmińsko-mazurskie voivodship sustainable development in the economic aspect. „Olsztyn Economic Journal”, $\mathrm{nr}$ 5(2/2010), s. 258-268.

\section{Streszczenie}

Badania objęły obszar województwa warmińsko-mazurskiego, które charakteryzuje się dużym udziałem obszarów prawnie chronionych. Opierając się na danych statystycznych publikowanych przez GUS oraz danych GDOŚ i RDOŚ w Olsztynie przeprowadzono analizę poziomą i pionową uwzględniająca podział na gminy wiejskie, miejskie i miejsko-wiejskie. Analiza dotyczyła zmian w dostępie do infrastruktury liniowej ochrony środowiska oraz zmian w udziale obszarów prawnie chronionych w trzech typach gmin, w latach 2005-2012. W wyniku badań stwierdzono duże dysproporcje w dostępności do infrastruktury ochrony środowiska w trzech typach gmin. Dysproporcje, choć wolnym tempie zmniejszały się. Jednocześnie przy utrudnionym dostępie do infrastruktury ochrony środowiska $w$ gminach wiejskich stwierdzono znacząco wyższe udziały obszarów prawnie chronionych niż w gminach miejskich i miejsko-wiejskich. Jednak dynamika zmian w przypadku obszarów prawnie chronionych charakteryzowała się stałym wynikiem od 2007 roku.

Słowa kluczowe: infrastruktura liniowa, ochrona środowiska, ochrona przyrody, zrównoważony dostęp, tempo zmian

Numer klasyfikacji JEL: Q01, Q58 